\title{
PROCESSOS ESTRUTURAIS: UMA TRANSIÇÃO ENTRE ESTADOS DE COISA PARA A TUTELA DOS DIREITOS ${ }_{-}{ }^{2}$
}

\section{STRUCTURAL LITIGATION: A TRANSITION BETWEEN STATES OF AFFAIRS FOR THE PROTECTION OF RIGHTS}

Matheus Souza Galdino Mestrando em Direito na Universidade Federal da Bahia. Especialista em Direito do Estado pela Faculdade Baiana de Direito. Procurador do Município de Salvador. Advogado. Salvador/BA. E-mail: galdino.matheus@yahoo.com.br

RESUMO: Com base em desdobramentos do que é sustentado em doutrina contemporânea, apresenta uma compreensão do processo estrutural, distinta, mas não incompatível, com a doutrina tradicional. Afirma que o fundamento distintivo do processo estrutural decorre de uma mudança de racionalidade (de causal para teleológica), direcionada a uma transição não imediata entre estados de coisa. Referida transição permite identificar as características dos direitos direta e indiretamente tutelados pelo processo estrutural. Ao fim é possível identificar o âmbito de atuação dos processos estruturais e sua função na tutela dos direitos.

PALAVRAS-CHAVE: Processos Estruturais. Medidas Estruturantes. Processo de Interesse Público. Processo de Direito Público. Tutela dos Direitos.

ABSTRACT: Based on unfolding of what is sustained in contemporary doctrine, it presents an understanding of the structural litigation, distinct but not incompatible with traditional doctrine. It affirms that the distinctive foundation of the structural litigation

\footnotetext{
${ }^{1}$ Artigo recebido em 13/04/2019 e aprovado em 02/08/2019.

${ }^{2}$ Este artigo é resultado do grupo de pesquisa "Transformações nas teorias sobre o processo e o Direito processual", vinculado à Universidade Federal da Bahia e cadastrado no Diretório Nacional de Grupos de Pesquisa do CNPQ (dgp.cnpq.br/dgp/espelhogrupo/7958378616800053). Esse grupo é membro fundador da "ProcNet - Rede Internacional de Pesquisa sobre Justiça Civil e Processo contemporâneo" (http://laprocon.ufes.br/rede-de-pesquisa)". Não há entidades financiadoras ou bolsa.
} 
stems from a change of rationality (from causal to teleological), directed to a nonimmediate transition between states of affairs. This transition allows the identification of the characteristics of rights directly and indirectly protected by the structural litigation. At the end it is possible to identify the scope of action of the structural litigation and their function in the protection of the rights.

KEY WORDS: Structural Litigation. Structural Injuction. Public Interest Litigation. Public Law Litigation. Protection of Rights.

SUMÁRIO: 1. Introdução - 2. Processo estrutural: entre meios e fins, ação e estados de coisa - 2.1 Causalidade e Teleologia - 2.2 Zweckrational: racionalidade referente a fins 2.3 Ação e estado de coisas - 3. Processo Estrutural e Tutela dos Direitos - 3.1 Distinção entre direito ao estado de coisas e direitos cuja efetivação decorre do alcance do estado de coisas - 3.2 - Características dos direitos tutelados pelo processo estrutural - 3.3. A tutela estrutural como um meio para o alcance das tutelas específicas 4. Conclusão - Referências.

\section{INTRODUÇÃo}

Nos Estados Unidos, o Estado da Califórnia, enfrentando um problema de difícil solução, em um processo judicial ${ }^{3}$, reduziu significativamente sua população carcerária, para os padrões considerados aceitáveis, segundo os termos processualmente fixados, saindo de 162.368 detentos no ano de 2011 para 132.911 detentos em $2013^{4}$.

O Brasil, pais sem grande histórico de efetiva recuperação de danos ambientais, frente a um dano de grandes proporções, consegue judicialmente ${ }^{5}$ que $73 \%$ das áreas terrestres atingidas por determinada degradação passem a contar com um cronograma de atividades para recuperação ambiental, a ser executado até o ano de $2020^{6}$.

\footnotetext{
${ }^{3}$ Brown v. Plata, 563 U.S. 493 (2011).

${ }^{4}$ Comparação entre os relatórios semestrais disponíveis no sítio do Departamento de Correções e Reabilitação da Califórnia. https://sites.cdcr.ca.gov/research/population-reports/ acesso em 29.03.2019.

${ }^{5}$ Ação Civil Pública no $93.8000533-4$, em curso na $1^{\text {a }}$ Vara Federal da Subseção Judiciária de Criciúma/SC.

${ }^{6}$ ARENHART, Sergio Cruz. Processos estruturais no direito brasileiro: reflexões a partir do caso da ACP do carvão. In: GRINOVER, Ada Pellegrini. WATANABE, Kazuo. COSTA, Susana Henriques da (Coord). $O$ Processo Para Solução de Conflitos de Interesse Público. Salvador: Jus Podivm, 2017. p. 475-492, p. 487.
} 
Rio de Janeiro. Ano 13. Volume 20. Número 3. Setembro a Dezembro de 2019

Periódico Quadrimestral da Pós-Graduação Stricto Sensu em Direito Processual da UERJ

Patrono: José Carlos Barbosa Moreira (in mem.). ISSN 1982-7636. pp. 358-385 www.redp.uerj.br

A Colômbia em franca crise de seu sistema prisional e sem qualquer perspectiva de uma mudança nessa área, após o ano de 1998, logra, por imposição judicial ${ }^{7}$, uma política que, em que pese não resolver o problema, alcança a geração de mais de 20 mil vagas em seu sistema carcerário ${ }^{8}$.

Tem-se em comum nos exemplos referidos a presença do que ficou conhecido na doutrina comparada como structural litigation ${ }^{9}$ ou, como vem sendo recebido na doutrina brasileira, processos estruturais ${ }^{10}$. Trata-se de modelo cuja utilização tem sido defendida como ocorrida em uma multiplicidade de casos como o fim da segregação racial em escolas públicas primárias ${ }^{11}$, a efetivação do direito à educação infantil pelo acesso a vagas em creches $^{12}$, a modificação na atuação de grandes empresas que cometem atos ilícitos ${ }^{13}$, a recuperação judicial de empresas em situação de crise $^{14}$, a melhoria da saúde pública ${ }^{15}$, entre outros ${ }^{16}$, são lembrados como casos que apenas receberam uma tutela adequada por que processados como processos estruturais.

\footnotetext{
${ }^{7}$ Corte Constitucional de Colômbia, Sentencia T -153, de 28 de abril de 1998.

${ }^{8}$ SANTOS, Helena Maria Pereira dos. VIEIRA, José Ribas. DAMASCENO, Luana Regina D'Alessandro. CHAGAS, Tayna Tavares das. Estado de Coisas Inconstitucional: Um estudo sobre os casos colombiano e brasileiro. Revista Quaestio Iuris. Vol. 08, nº. 04, Número Especial, Rio de Janeiro, 2015, p. 2.602.

${ }^{9}$ FISS, Owen. Two models of adjudication. In: DIDIER JR. Fredie. JORDÃO, Eduardo Ferreira (coord.). Teoria do Processo: panorama doutrinário mundial. Salvador: Jus Podivm, 2008. p.761-767.

${ }^{10}$ Nesse sentido veja-se a respeito recente obra de mesmo nome: JOBIM, Marco Félix. ARENHART, Sérgio Cruz (Org.). Processos Estruturais. Salvador: Jus Podivm, 2017.

${ }^{11}$ FISS, Owen. Two models of adjudication, op. cit., p. 762-764.

${ }^{12}$ COSTA, Susana Henriques da. Acesso à Justiça: Promessa ou Realidade? Uma análise do Litígio sobre Creche e pré-escola no Município de São Paulo. In: GRINOVER, Ada Pellegrini. WATANABE, Kazuo. COSTA, Susana Henriques da (Coord.). O Processo Para Solução de Conflitos de Interesse Público. Salvador: Jus Podivm, 2017. p. 449-473.

${ }^{13}$ OSNA, Gustavo. Nem "Tudo", Nem "Nada" - Decisões Estruturais e efeitos jurisdicionais complexos, In: JOBIM, Marco Félix. ARENHART, Sérgio Cruz (Org.). Processos Estruturais. Salvador: Jus Podivm, 2017. p. 177-202.

${ }^{14}$ BATISTA, Felipe Vieira. A Recuperação Judicial como Processo Coletivo. Dissertação (Mestrado em Direito) - Faculdade de Direito, Universidade Federal da Bahia, Salvador, 2017.

${ }^{15}$ CASTELO, Fernando Alcântara. Direito à Saúde e Decisões Estruturais: Por uma judicialização mais racional e eficiente. Revista de Processo. São Paulo: RT, 2017, ano 42, v. 274, p. 317-342. BERGALLO, Paola. La causa "Mendoza": una experiencia de judicialización cooperativa sobre el derecho a la salud. In: GARGARElla, Roberto (org.). Por una justicia dialógica: el Poder Judicial como promotor de la deliberación democrática Buenos Aires: Siglo XXI Editores, 2014, e-book.

${ }^{16}$ Uma contextualização desta utilização em todo o mundo no que diz respeito aos direitos sociais veja-se em GRAVITO, César Rodrigues. El activismo dialógico y el impacto de los fallos sobre derechos sociales. In: GARGARELlA, Roberto (org.). Por una justicia dialógica: el Poder Judicial como promotor de la deliberación democrática Buenos Aires: Siglo XXI Editores, 2014, e-book.
} 
Verifica-se, todavia, ainda em muitos casos, a não utilização dos processos estruturais, seja por ausência de sua compreensão, de sua área de atuação ou desconhecimento de sua função o que tem implicado na ausência de tutela dos direitos.

Este artigo parte de critério, distinto (mas não incompatível) dos tradicionais, segundo o qual, a diferença do modelo processual decorre de uma mudança de racionalidade, de uma relação causa-efeito (retrospectiva) para uma relação meio-fim (prospectiva) entre fatos e efeitos. Tal distinção possibilitará a compreender as espécies de direitos em discussão, o campo de atuação e a função dos processos estruturais na tutela dos direitos, sobretudo como um meio para efetividade das tutelas específicas.

\section{PROCESSO ESTRUTURAL: ENTRE MEIOS E FINS, ENTRE AÇÃO E ESTADOS DE COISA}

\section{$2.1 \quad$ CAUSALIDADE E TELEOLOGIA}

Em que pese controvérsias existentes acerca do momento e do local em que os processos aqui denominados estruturais se originaram ${ }^{17}$, parece inquestionável que a doutrina e as discussões específicas a seu respeito se formaram na segunda metade do século XX, especialmente após a decisão da Suprema Corte dos Estados Unidos nos casos Brown v. Board of Education of Topeka e Brown II ${ }^{18}$, onde restou imposta uma transformação do sistema de ensino dual - com escolas para crianças negras e escolas para crianças brancas - em um sistema unitário, com escolas integradas.

O modo como essa e outras ${ }^{19}$ transformações sociais restaram qualificadas pela

\footnotetext{
${ }^{17}$ Para Owen Fiss, nos anos seguintes a 1954 e 1955, como resultado do esforço para por em prática o que foi decidido em Brown v. Board of Education of Topeka. FISS, Owen. The Supreme Court 1978 term: Foreword: the forms of justice. Havard Law Review, v. 93, n.1, 1979. p.1-58, p. 2. Para Abram Chayes, algum momento após 1.875 , por um corpo de legislação explicitamente projetado para modificar e regular os arranjos sociais e econômicos básicos. CHAYES, Abram. The Role of the Judge In Public Law Litigation. Havard law review. Vol. 89, n. 7, maio de 1976. p. 1281-1316. p. 1282-1283, p. 1288. Para Eisenberg e Yeazell, possui precedentes no common law inglês, desde a idade média. EISENBERG, Theodore. YEAZELL, Stephen C.. The Ordinary and the Extraordinary in Institutional Litigation. Havard law review. Vol. 93, n. 3, january de 1980. p. 465-517.

${ }^{18}$ Brown v. Board of Education of Topeka, 347 U.S. 483 (1954) e 349 U.S. 294 (1955).

${ }^{19}$ Cite-se por exemplo o caso Holt v. Server que questionou a constitucionalidade do sistema prisional do Arkansas, marcado por violações dos direitos humanos dos detentos. Em verdade são ao menos seis causas
} 
doutrina se confunde com as diversas concepções acerca do que aqui se entende por processo estrutural ${ }^{20}$. Sem qualquer pretensão de incompatibilidade abstrata com as concepções tradicionais $^{21}$, partindo de uma contemporânea visão é possível uma abordagem distinta para sua compreensão.

Segundo compreende Mariela Puga, acerca do que denomina causalidade estrutural $^{22}$, os processos estruturais são marcados por uma forma de nexo causal que privilegia o modo como certos fatos são fonte de violação de direitos, guiado não por objetivos sancionatórios, mas por objetivos de identificação e correção da violação.

Em verdade, ao vincular a causalidade estrutural a objetivos de correção da violação, é possível questionar se de fato se estar a falar de causalidade ou se não seria o caso de dar

que tramitaram entre 1969 e 1982: Holt v. Sarver, Holt v. Sarver II, Holt v. Hutto, Finney v. Arkansas Board of Corrections, Finney v. Hutto I e Finney v. Hutto II.

${ }^{20}$ Para muitos, seguindo a concepção de Abram Chayes, trata-se do public law litigation, o qual inverte muitas das características do modelo tradicional de processo que tem por enfoque uma reivindicação sobre o funcionamento de políticas públicas (CHAYES, Abram. The Role of the Judge In Public Law Litigation, op. cit., p. 1302.). Para outros, seguindo a proposta de Owen Fiss, trata-se da structural reform que tem por foco conceitual o exercício da função do Poder Judiciário dar significado aos valores constitucionais, quando esta exige um embate entre o judiciário e burocracias estatais (FISS, Owen. The Supreme Court 1978 term, op. cit., p.2). Outros ainda, com base nos estudos de Lon L. Fuller, é a policentria a principal marca, ante a existência de diversos centros distintos de interesses, sendo cada um deles relacionado a todos os outros e onde a solução de um depende da solução de todos (FULLER, Lon L. The Forms and Limits of Adjudication. Harvard Law Review, Vol. 92, No. 2 , 1978, p. 353-409). Para Eisenberg e Yeazell, por outro lado, se trata de um modelo institucional de litígio que possui precedentes no common law inglês, da idade média. EISENBERG, Theodore. YEAZELL, Stephen C.. The Ordinary and the Extraordinary in Institutional Litigation, op. cit., p. 482.

${ }^{21} \mathrm{Em}$ verdade, em que pese não expressarem explicitamente, a ideia de que o processo estrutural possui uma racionalidade teleológica (prospectiva) é pressuposta por diversos autores que tratam da matéria. Abram Chayes se refere a uma instrução que não é histórica e adjudicativa, mas prospectiva e legislativa (CHAYES, Abram. The Role of the Judge In Public Law Litigation, op. cit., p. 1296). O caráter prospectivo de algumas decisões no mesmo período foi identificado por Doug Redleman. (RENDLEMAN, Doug R. Prospective Remedies in Constitutional Adjudication. West Virginia Law Review. V. 78. N. 2, 1976. p. 163.). Para Owen Fiss a medida judicial é considerada em termos instrumentais, considerando o valor constitucional ameaçado sendo escolhida entre as várias formas de atingir este propósito (FISS, Owen. The Supreme Court 1978 term: Foreword: the forms of justice, op. cit., p.50). Na doutrina contemporânea veja-se, ARENHART, Sérgio Cruz. Decisões Estruturais no Direito Processual Civil Brasileiro. Revista de Processo. São Paulo: RT, 2013, ano 38, v. 225, p. 389-410. p. 400. DIDIER JR., Fredie. ZANETI JR., Hermes. OLIVEIRA, Rafael Alexandria de. Notas sobre as Decisões Estruturantes. In: JOBIM, Marco Félix. ARENHART, Sérgio Cruz (Org.). Processos Estruturais. Salvador: Jus Podivm, 2017. p. 354-368, p. 356. MARÇAL, Felipe Barreto. Medidas e processos estruturantes (multifocais): características e compatibilização com o ordenamento processual brasileiro. Dissertação (Mestrado em Direito) - Faculdade de Direito, Universidade do Estado do Rio de Janeiro, 2018, p. 161.

22 PUGA. Mariela. p. Litígio Estructural. Tesis Doctoral. Faculdade de Derecho de La Universidad de Buenos Aires. 2013. p. 29-31. 
lugar a outro raciocínio, frente ao qual a causalidade é tradicionalmente ${ }^{23}$ contrastada: a teleologia ${ }^{24}$. Por esta distinção, a causalidade, via de regra, aponta para o passado e vertese sobre a investigação e descoberta de fatos ocorridos, ao passo que, a teleologia, aponta para o futuro e verte-se, entre outras possibilidades, sobre a previsão da ocorrência de eventos e resultados. A relação causal se apresenta como uma relação entre causa e efeito e a relação teleológica se apresenta como uma relação entre meio e fim ${ }^{25-26}$.

A causalidade no mundo jurídico é bem retratada na teoria do fato jurídico ${ }^{27}$. A norma jurídica é causa do fato jurídico e este o é da eficácia jurídica ${ }^{28}$ Fala-se então em causalidade jurídica na relação de determinação entre o fato jurídico e sua eficácia, o que exige um olhar para algo já ocorrido. A incidência da norma depende de que, no mundo, os fatos descritos nos suportes fático hipotéticos tornem-se realidade, ocorram $(=$ se concretizem) e, por fim, sejam da ciência de alguém ou que seja passível de prova ${ }^{29}$, deste modo, o preceito previamente previsto na norma indica os efeitos atribuídos ${ }^{30}$ ao fato jurídico resultante.

No plano processual esta realidade se reflete, vez que a denominada causa de pedir

\footnotetext{
${ }^{23}$ Georg H. von Wright afirma que a investigação científica em uma perspectiva ampla pode ser associada, à luz da histórica intelectual, a duas tradições uma acerca da causalidade e outra da teleologia. A causalidade se ligaria à tradição galileana e a teleologia à tradição aristotélica. WRIGHT, Georg Henrik von. Explanation and Understanding. Cornell University Press. Ithaca, New York, 1971.p. 1-2.

${ }^{24}$ WRIGHT, Georg Henrik von. Explanation and Understanding, op. cit., p. 83.

${ }^{25}$ Sendo possível também tomar a causalidade em uma acepção mais ampla para entender haver também nela uma relação meio/fim como faz Lourival Vilanova. VILANOVA, Lourival. Causalidade no Direito. $4^{\mathrm{a}} \mathrm{ed}$. São Paulo: Editora Revista dos Tribunais, 2000, p. 101. Neste caso, seria conveniente diferenciar uma causalidade retrospectiva e uma causalidade (ou determinismo e probabilidade como seria mais adequado) prospectiva. Aquela própria dos processos não estruturais, esta própria dos processos estruturais. Também Georg H. von Wright entende que, em termos gerais, a relação entre meios e fins é causal. WRIGHT, Georg Henrik von. Rationality: Means and Ends. Rivista/Journal Epistemologia IX, Genova, Casa Editrice TilgherGenova sas, 1986.p. 57-72, p. 59. Por outro lado, o autor demonstra a distinção ao afirmar que quando queremos explicar o comportamento teleologicamente começamos a partir da conclusão e trabalhamos de volta às premissas. WRIGHT, Georg Henrik von. Explanation and Understanding, op. cit., p. 119.

${ }^{26}$ WRIGHT, Georg Henrik von. Explanation and Understanding. op. cit., p. 100.

27 Teoria proposta por Pontes de Miranda no Tratado de Direito Privado, sobretudo nos tomos I ao VI. MIRANDA, Pontes de. Tratado de Direito Privado. São Paulo: Editora Revista dos Tribunais. 2012. Referida teoria foi bastante difundida por Marcos Bernardes de Mello. MELLO, Marcos Bernardes de. Teoria do Fato Jurídico: plano da eficácia: $1^{\circ}$ parte. 10a ed. São Paulo: Saraiva, 2015; MELLO, Marcos Bernardes de. Teoria do Fato Jurídico: plano da existência: $21^{\text {a }}$ ed. São Paulo: Saraiva, 2017; MELLO, Marcos Bernardes de. Teoria do Fato Jurídico: plano da validade: 14ª ed. São Paulo: Saraiva, 2015.

${ }^{28}$ MELLO, Marcos Bernardes de. Teoria do Fato Jurídico: plano da eficácia, op. cit., p. 35.

${ }^{29}$ MELLO, Marcos Bernardes de. Teoria do Fato Jurídico: plano da existência, op. cit., p. 142-143.

${ }^{30}$ MELLO, Marcos Bernardes de. Teoria do Fato Jurídico: plano da existência, op. cit., p. 113.
} 
tem, em regra, por conteúdo a situação substancial preexistente ${ }^{31}$, sendo o processo o meio para a efetivação de determinados efeitos jurídicos ${ }^{32}$ daquela decorrentes. Cada fato ou conjunto de fatos ocorridos e suscetíveis de produzir o efeito jurídico pretendido pelo autor constitui assim uma causa de pedir $^{33}$. Sequencialmente a estrutura do processo não estrutural se apresenta nos seguintes termos: Causa $=>$ efeito $=>$ processo (certifica a causa e efetiva o efeito) $\Rightarrow>$ efetividade.

Analiticamente, o processo investiga determinados fatos e a eventual incidência normativa sobre estes, o que implica na atribuição, aos fatos jurídicos resultantes, dos efeitos previstos normativamente. O processo se presta para possibilitar que, após referida investigação, que os efeitos sejam efetivados ${ }^{34}$, e se a tutela dos direitos assim exigir (vide item 3.2 abaixo), inclusive no mundo dos fatos.

Como exemplos: a) em uma ação de alimentos, há uma relação de família onde alguém precisa de alimentos e alguém pode pagar por eles, causa cujo efeito é o direito aos alimentos, a ser efetivado processualmente, se necessário; b) em uma ação indenizatória, um dano culposo é a causa cujo efeito é o direito a indenização, a ser efetivado processualmente, se necessário; c) em uma ação anulatória, um contrato celebrado com um vício de consentimento é a causa cujo efeito é o direito de anular o contrato, a ser efetivado processualmente, se necessário.

Em certas situações de direito material, a eficácia jurídica atribuída aos fatos jurídicos, não pode ser efetivada de imediato ${ }^{35}$ exigindo que o processo viabilize o alcance de determinado estado fático ${ }^{36}$, o qual, possibilitará como sua consequência, a efetividade

\footnotetext{
${ }^{31}$ TUCCI, José Rogério Cruz e. A causa de pedir no processo civil. 2. Ed. São Paulo: Editora Revista dos Tribunais, 2001, p. 127-132.

32 TUCCI, José Rogério Cruz e. A causa de pedir no processo civil op. cit., p. 131.

33 MOREIRA, José Carlos Barbosa. O novo processo civil brasileiro: exposição sistemática do procedimento. $23^{\text {a }}$ ed. Rio de Janeiro, Forense, 2005, p. 15.

${ }^{34}$ Marcos Bernardes de Melo distingue a eficácia jurídica, conjunto de efeitos imputados pela norma, de efetividade do direito (ou eficácia do direito), esta enquanto efetiva realização da norma no meio social, em outras palavras, o tornar realidade as circunstâncias por ela imputadas. MELLO, Marcos Bernardes de. Teoria do Fato Jurídico: plano da eficácia op. cit., p. 18-19. Também Lourival Vilanova utiliza a expressão efetivação e palavras correlatas em sentido semelhante, inclusive expressamente se referindo ao fenômeno da exigência coativa perante o órgão estatal no tratamento da relação processual. VILANOVA, Lourival. Causalidade no Direito, op. cit., p. 189.

${ }^{35}$ Isso é admitido para outras hipóteses por Marcos Bernades de Mello. MELLO, Marcos Bernardes de. Teoria do Fato Jurídico: plano da eficácia, op. cit., p. 104.

${ }^{36} \mathrm{Um}$ estado fático, na teoria do fato jurídico, envolve situação permanente no tempo, resultante de acontecimentos. MELLO, Marcos Bernardes de. Teoria do Fato Jurídico: plano da existência, op. cit., p. 92.
} 
inicialmente prevista.

Para tais situações de direito material não se presta um processo que trabalha com uma relação causa-efeito, sendo necessária a compreensão de uma relação processual que tome o estado fático pretendido como fim e articule os meios para seu alcance ${ }^{37}$ e dessa forma tomará indiretamente a causa e o efeito ${ }^{38}$. Sequencialmente seria a seguinte estrutura: Causa=>efeito $=>$ processo (certifica o fim e o efetiva por meios) $=>$ efetividade.

Neste caso, o processo não se detém sobre uma relação de causa - efeito, mas pressupondo determinada causa e que a necessidade de alcance de determinado efeito exige o alcance de determinado estado fático, buscando este como um fim, definindo e executando os meios necessários, adequados e proporcionais para tanto.

O caso Brown parece muito adequado como exemplo. A Suprema Corte do Estados Unidos decidiu nesse caso que a segregação racial nas escolas públicas era inconstitucional $^{39}$, mas a decisão não teve como efetividade imediata o seu fim como podia ser de se esperar. A corte entendeu que não era possível o pretendido ${ }^{40}$, vez que, conforme já se afirmou, o próprio direito material exigia uma transição ${ }^{41-42}$ para um estado de coisas futuro, com estrutura distinta e que fora indicado como objetivo. A decisão sobre os meios, o tempo necessário para se alcançar, e o grau de alcance de referido estado de coisas foi o objeto dos processos estruturais que se formaram na origem.

\footnotetext{
${ }^{37}$ Quando queremos explicar o comportamento teleologicamente, começamos, por assim dizer, a partir da conclusão e trabalhamos de volta às premissas. WRIGHT, Georg Henrik von. Explanation and Understanding, op. cit., p. 119.

${ }^{38} \mathrm{Em}$ verdade parece ocorrer uma inversão entre a relação causa-efeito e a relação meio-fim. Se no processo não estrutural, numa fase de conhecimento, se verifica/conhece de uma causa ocorrida que implica em efeitos, no processo estrutural, numa fase de conhecimento, se verifica/conhece de um fim (não ocorrido, muito pelo contrário) a ser perseguido e cuja busca implica em meios que "causarão" o alcance do fim. Lá (relação causa-efeito) se efetiva o efeito com base na causa, aqui (relação meio-fim) se efetiva a causa (meios) com base no efeito que se pretende (fim).

${ }^{39}$ Brown v. Board of Education of Topeka, 349 U.S. 294 (1955).

${ }^{40}$ É possível refletir que a simples admissão de uma ou algumas crianças negras em uma escola majoritariamente composta por alunos brancos, professores brancos, funcionários brancos, poderia implicar em uma discriminação ainda maior.

${ }^{41}$ Conclusão a que chegou Ronald Dworkin ao afirmar com base em julgamento do caso pelo seu juiz fictício Hércules: "Assim, ele [Hércules] deve perguntar-se qual procedimento acarretará a melhor proteção para as crianças negras que buscam uma educação integrada, e pode bem descobrir que a exigência de que a integração seja efetuada da noite para o dia não resultará em proteção alguma". DWORKIN, Ronald. $O$ Império do Direito. Tradução de Jefferson Luiz Camargo. São Paulo: Martins Fontes, 1999. p.465.

${ }^{42}$ RENDLEMAN, Doug R. Brown II "All Deliberate Speed" at Fifty: A Golden Anniversary or A Mid-Life Crisis for the Constitutional Injunction as a School Desegregation Remedy? San Diego Law Review. V.41, 2004, p. 1575-1616., p. 1585-1586.
} 
A compreensão das características do processo estrutural por uma perspectiva não causal, mas teleológica exige a compreensão da racionalidade existente entre meios e fins. Para tal proposito é possível partir da compreensão da palavra zweckrational cujo conceito é atribuído a Max Weber ${ }^{43}$ e que pode ser traduzida, por uma racionalidade referente a fins.

Segundo Weber age de maneira racional referente a fins "quem orienta sua ação pelos fins, meios e consequências secundárias, ponderando ${ }^{44}$ racionalmente tanto os meios em relação às consequências secundárias, assim como os diferentes fins possíveis entre si. $^{45}$ "

Com base nos estudos de Georg H. von Wright ${ }^{46}$, o termo zweckrationalität pode abranger uma forma adicional ${ }^{47}$ de racionalidade muito útil ao presente estudo: a busca de fins como meio para fins adicionais. Não se trata aqui de uma deliberação entre meios e consequências secundárias ou entre meios e fins, mas de uma deliberação entre diferentes fins, os quais estariam sujeitos ao controle racional através das consequências resultantes de seu alcance ${ }^{48}$.

\footnotetext{
${ }^{43}$ Para Max Weber toda ação pode ser determinada: 1) de modo racional referente a fins; 2) de modo racional referente a valores; 3) de modo afetivo; 4) de modo tradicional; A zweckrational seria a ação de modo racional referente a fins. WEBER, Max. Economia e Sociedade: fundamentos da sociologia compreensiva. V. 1. $3^{\text {a }}$ Ed. Trad. Regis Barbosa e Karen Elsabe Barbosa. Brasília, Ed. Universidade de Brasília, 2000. p. 16. ${ }^{44}$ Ponderação não deve ser lida, obrigatoriamente, no sentido corrente da linguagem jurídica. Wright com base na expressão alemã Abwägung entende também como atividade ou processo de deliberação. WRIGHT, Georg Henrik von. Rationality: Means and Ends, op. cit., p. 57.

${ }^{45}$ WEBER, Max. Economia e Sociedade: fundamentos da sociologia compreensiva, op. cit., p. 16.

${ }^{46}$ WRIGHT, Georg Henrik von. Rationality: Means and Ends. op. cit., p. 61-62. Para o autor, é pouco provável que Weber tenha concebido a expressão nesse sentido, mas o termo também o abrange.

${ }^{47}$ Também haveria para o autor uma racionalidade entre meios e consequência secundárias, a qual tem lugar quando há vários meios que podem levar ao fim. Nestes casos a preferência por um meio em relação ao outro leva em consideração análises como a probabilidade de se alcançar o fim, a avaliação do tempo, do custo, do grau de dificuldade e dos incômodos que cada um dos meios proporciona. Ademais, a avaliação resultante de tais análises pode ser combinada com a consideração de que a obtenção do fim é um valor positivo e o uso dos meios, um valor negativo (um preço a pagar) para o alcance do fim sendo aí incluído um outro aspecto de racionalidade. WRIGHT, Georg Henrik von. Rationality: Means and Ends, op. cit., p. 59-62.

${ }^{48} \mathrm{O}$ autor traz um exemplo elucidativo. Uma pessoa que quer ascender profissionalmente em uma empresa, planeja sua educação como um meio para esse fim e ele consegue alcançando a renda alta que esperava como resultado. Ocorre que, também precisa assumir responsabilidades pesadas e como consequência, acaba negligenciando sua família e, trabalhando demais, prejudica sua saúde. Torna-se óbvio para tal pessoa que ela teria uma vida melhor se tivesse estabelecido objetivos menos ambiciosos A avaliação do fim a ser alcançado se procede, assim, por determinadas consequências que sua obtenção permitirá. No exemplo, não se tratou de
} 
O resultado alcançado não demonstra ausência de racionalidade entre meios e fins, mas sim da escolha entre os fins possíveis, considerando a consequência que implica. É nesse sentido que a racionalidade sobre fins pode ser reconstruída com a preocupação em ser um meio para fins adicionais. Utilizando da alegoria de von Wright, o fim é então considerado como uma espécie de "plataforma"49 a ser alcançada não como um fim em si mesmo, mas para o alcance de outros fins que sua obtenção permitirá.

Novamente um exemplo. Em um processo de recuperação judicial de empresas, a preservação da empresa é o objetivo do processo. Ocorre que este não é visado como um objetivo puro e simples. Trata-se do alcance de um objetivo que servirá como plataforma para efetivação de outros fins, tais como: a manutenção dos empregos dos trabalhadores, o pagamento dos credores (mesmo que parcial, os quais em alguns casos não seriam efetuados sequer parcialmente), a continuidade da geração e recolhimento de tributos, a manutenção da cadeia produtiva de que participa etc.

\subsection{AÇÃO E ESTADO DE COISAS}

\subsubsection{Estado de coisas}

Acima a racionalidade para a escolha dos fins foi apresentada figurativamente como uma espécie de plataforma que possibilita a efetivação de fins adicionais. A expressão filosófica que melhor corresponde à ideia é estado de coisas, especialmente se relacionado ao conceito de ação em uma lógica de mudança.

$\mathrm{O}$ que foi indicado como relação entre meio, fim e fins adicionais aqui se prossegue como uma relação entre ação (meio), estado de $\operatorname{coisas}^{50}$ (fim) e tutela de direitos (fins adicionais). Tal relação pode ser aprofundada pela compreensão do estado de coisas em

uma busca por ascensão profissional simplesmente, mas como um meio de, possuindo uma remuneração melhor, ter uma vida melhor. $\mathrm{O}$ fim pretendido foi alcançado, mas as consequências dele esperados, não o foram. A escolha do fim, portanto, careceu de racionalidade. WRIGHT, Georg Henrik von. Rationality: Means and Ends, op. cit., p. 65-66.

${ }^{49}$ Nas palavras do autor, "The end is then regarded as a kind of 'platform' to be attained not (perhaps) 'for its own sake' as much as for some consequences which its attainment is likely to have”. WRIGHT, Georg Henrik von. Rationality: Means and Ends, op. cit., p. 64-65.

${ }^{50}$ PECZENIK, Aleksander. On Law and Reason. Lexington: Springer, 2008, p. 225. 
transição, o qual recebeu especial atenção nos trabalhos de Georg H. von Wright ${ }^{51}$, inicialmente classificando aquele como espécie de fato ao lado de processos e eventos ${ }^{52}$.

Segundo Wright, entre os eventos, existe um que é considerado o evento principal, um par ordenado de dois estados de coisas, cuja relação de ordenação é uma relação sucessiva no tempo, o evento em verdade é a mudança ou transição do estado de coisas que se obtém na ocasião anterior para o estado que se obtém na ocasião posterior, ou, em outras palavras, a transição de um mundo que contém o estado inicial para um mundo que contém o estado final ${ }^{53}$. Esse evento principal o autor representa por meio da expressão $p T q^{54}$, a qual descreve uma transição ${ }^{55} \mathrm{~T}$ de um p-mundo para um q-mundo ${ }^{56}$.

Assim, em processos judiciais buscando a reforma de sistemas prisionais que atentam contra a integridade de detentos, o "p-mundo" corresponde ao estado de coisas de um sistema prisional que atenta contra a dignidade dos presos e o "q-mundo" corresponde ao estado de coisas de um sistema prisional que sustenta o respeito à dignidade dos presos, na forma das normas vigentes, o mesmo exemplo poderia ser estendido a outros campos como acesso a vagas em creches, fim de segregação racial, recuperação do meio ambiente etc ${ }^{57}$.

\footnotetext{
${ }^{51}$ Também se fundamenta no conceito de Wright para tratar de estado de coisas entre outros Robert Alexy e Humberto Ávila respectivamente, ALEXY, Robert. Teoria da Argumentação Jurídica. $3^{\mathrm{a}}$ ed. Rio de Janeiro: Forense, 2011, p. 238 e ÁVILA, Humberto. Teoria dos Princípios: da definição à aplicação dos princípios jurídicos. 18 ${ }^{\text {a }}$. Ed. São Paulo: Malheiros, 2018. p.95

${ }^{52}$ Segundo o autor existem vários tipos de fatos, as três espécies que utiliza não esgotam o gênero. $\mathrm{O}$ autor distingue os três, sobretudo, por meio de exemplos. O processo seria algo que está acontecendo, tem uma continuidade "dinâmica", por exemplo, está chovendo em determinado lugar e tempo, é algo que continua e acontece durante certo período. Um estado de coisas é algo que tem ínsita uma continuidade estática, e é analisado em determinado momento, por exemplo nas afirmações de que a população de um país é maior que a de outro ou de que determinado objeto se encontra sobre uma mesa. Por fim, um evento seria um acontecimento, sem continuidade, algo instantâneo, no exemplo do autor "Brutus matou César" WRIGHT, Georg Henrik von. Norm and action: a logical enquiry. Londres, Routledge \& Kegan Paul, 1963.p. 25-27.

${ }^{53} \mathrm{O}$ autor admite que os estados de coisas também sejam chamados de características dos mundos. WRIGHT, Georg Henrik von. Norm and action, op. cit., p. 28.

${ }^{54}$ Eis a expressão que pode ser considerada a expressão geral do objeto dos processos estruturais.

${ }^{55}$ Doug Rendleman, em uma exemplificação do que se afirma, disserta sobre Brown v. Board of Education of Topeka II indicando que o tribunal não ordenou uma injunção imediata, em vez disso, iniciou um período de transição dizendo aos juízes que mantivessem a jurisdição sobre as ações judiciais até que os direitos fossem implementados. RENDLEMAN, Doug R. Brown II "All Deliberate Speed" at Fifty, op. cit., p. 1585-1586.

${ }^{56}$ WRIGHT, Georg Henrik von. Norm and action, op. cit., p. 28.

${ }^{57}$ Os exemplos poderiam prosseguir: Nos processos judiciais buscando o fim da segregação racial em escolas públicas primárias, o "p-mundo" corresponde ao estado de coisas em que ocorre a segregação racial e o "qmundo" corresponde ao estado de coisas em que se está possibilitada a existência de escolas integradas. Em processos judiciais para a recuperação judicial de empresas em situação de crise, o "p-mundo" corresponde ao estado de coisas onde uma situação de crise põe em risco o prosseguimento da atividade empresarial e o
} 


\subsubsection{Ação, estado de coisas e tutela de direitos}

Por ação se entende o provocar uma transição entre estados de $\operatorname{coisas}^{58}$ (o provocar uma mudança no mundo). O agir não é a mudança no mundo, mas sua causa. A ação causa o estado de coisas. A transformação no estado de coisas é resultado de uma ação. Assim se relaciona ação e estado de coisas ${ }^{59}$. A transformação no mundo, pode acontecer também enquanto efeito da transição entre estados de coisa provocada pela ação. A segunda transformação é um efeito da primeira. A primeira transformação é efetuada através da ação, é resultado de um ato, a segunda é consequência do resultado da ação ${ }^{60}$.

Um exemplo do autor pode auxiliar na compreensão. $\mathrm{O}$ ato de abrir uma janela altera um estado de coisas, de um mundo onde a janela está fechada para um mundo onde a janela está aberta ${ }^{61}$. A abertura da janela é o resultado da ação. Há uma relação direta e intrínseca entre ato de abrir a janela e o resultado, uma janela aberta. Ocorre que, como efeito desse resultado (uma janela aberta), pode ocorrer de o cômodo no qual se encontra a janela ter um aumento de temperatura. Referido efeito não depende apenas da transição entre os estados de coisa (de janela fechada para janela aberta) e, portanto, não decorre somente da ação que provocou a transição entre os estados de coisa.

O efeito decorrente do resultado da ação depende de outras características do mundo. No caso, que a temperatura do lado de fora da janela esteja superior à temperatura interna do cômodo. Não sendo o caso, ou o efeito não ocorreria (se de mesma temperatura) ou ocorreria o efeito inverso, uma queda de temperatura no cômodo. Diferentemente da relação entre um ato e seu resultado, a relação entre um ato e os efeitos do resultado do ato (estado de coisa final) é extrínseca (indireta) ${ }^{62}$.

Esse raciocínio traz implicações ao trato dos processos estruturais. Conforme se

\footnotetext{
"q-mundo" corresponde ao estado de coisas onde a empresa se encontra recuperada. Em processos estruturais para recuperação de áreas ambientalmente degradadas, o "p-mundo" corresponde ao estado de coisas onde uma área ambiental necessita de recuperação e o "q-mundo" corresponde ao estado de coisas em que referida área ambiental se encontra recuperada, conforme parâmetros processualmente definidos.

${ }^{58}$ WRIGHT, Georg Henrik von. Norm and action,op. cit., p. 35.

${ }^{59}$ Em sentido semelhante Peczenik, PECZENIK, Aleksander. On Law and Reason, op. cit., p. 225.

${ }^{60}$ WRIGHT, Georg Henrik von. Norm and action, op. cit.,p. 39.

${ }^{61} \mathrm{O}$ exemplo é de George H. von Wright. WRIGHT, Georg Henrik von. Norm and action, op. cit., p. 39.

${ }^{62}$ WRIGHT, Georg Henrik von. Norm and action, op. cit., p. 40.
} 
concluiu em acima (item 2.1), em certas situações de direito material a eficácia jurídica atribuída aos fatos jurídicos (leia-se aqui, tutela do direito), não pode ser efetivada de imediato, exigindo previamente o alcance de determinado estado fático.

Ocorre que, em que pese a relação intrínseca entre ação e estado de coisas, a tutela dos direitos deste decorrentes depende, ainda, de outras características do mundo, mantendo uma relação extrínseca com a ação. Isso implica que o estado de coisas previsto como adequado à efetivação de determinados direitos pode deixar entre, outras razões, por uma "evolução ou desenvolvimento não previsível de um fato anterior" ${ }^{63}$, tornando, por consequência, inadequados os meios (ações) antes previstos.

A compreensão pode ser facilitada com o exemplo do caso das creches no Município de São Paulo, onde, por meio de Ação Civil Pública ajuizada em 2008 (Processo n ${ }^{\circ}$ 0150735-64.2008.8.26.0002) por diversas entidades do terceiro setor ${ }^{64}$, e ante o grande quantitativo de crianças não atendidas (cuja lista de espera oficial registrava 181.701 crianças), se pleiteou a efetivação da política pública, sendo julgada procedente a demanda determinando a criação de $150.000^{65}$ vagas a serem disponibilizadas entre 2013-2016, em referido período o cumprimento da decisão totalizou 106.743 vagas criadas ${ }^{66}$. Ante o cumprimento parcial do quanto previsto para o período de 2013-2016, em 2017, fora processualmente reestabelecida uma meta quantitativa para a criação de vagas sendo firmado o compromisso de criação de 85.500 vagas até $2020^{67}$.

Ocorre que, inicialmente, fora prevista a criação de 150.000 vagas até 2016, tendo sido atendido, até 2016, o quantitativo de 106.743 vagas. Em um raciocínio não estrutural, em 2017, faltariam cerca de 43.257 vagas a serem disponibilizadas. Ocorre que, os efeitos previstos para serem atendidos até 2016 não mais são alcançáveis com o quantitativo antes

\footnotetext{
63 Trata-se de relação que carrega ínsita potencial e dinâmica quebra de estabilidade no sentido defendido por Cabral. CABRAL, Antonio do Passo. Coisa julgada e preclusões dinâmicas: entre continuidade, mudança e transição de posições processuais estáveis. $3^{a}$ ed. Salvador: Jus Podivm, 2019. p. 622-623.

${ }^{64}$ Ação Educativa Assessoria, Pesquisa e Informação; Instituto de Cidadania Padre Josimo Tavares; Casa dos Meninos; Centro de Direitos Humanos e Educação Popular de Campo Limpo (CDHEP); e Associação Internacional de Interesses à Humanidade Jd. Emídio Carlos e Irene, todas integrantes do "MOVIMENTO CRECHE PARATODOS".

65 Dados constantes do Acórdão no 2013.0000792670 da Câmara Especial do Tribunal de Justiça de São Paulo nos autos da Apelação nº 0150735-64.2008.8.26.0002, p. 31.

66 Conforme notícia divulgada no sítio do Tribunal de Justiça de São Paulo https://www.tjsp.jus.br/Noticias/Noticia?codigoNoticia=43765 acesso em 05/03/2019.

67 Inteiro teor do acordo homologado disponível no site do Tribunal de Justiça de São Paulo < http://www.tjsp.jus.br/Noticias/Noticia?codigoNoticia=48767\&pagina=24> acesso em 05/03/2019.
} 
indicado como estado ideal de coisas. Feita então uma projeção, até 2020 a previsão é que, ceteris paribus, seja necessária então a criação de 191.743 vagas, sendo esse, quantitativamente, o novo estado de coisas necessário a tutela dos direitos previstos normativamente. Referida compreensão deve ser pressuposta no que adiante se concluirá da relação entre processo estrutural e tutela dos direitos.

\subsection{DISTINÇÃO ENTRE DIREITO AO ESTADO DE COISAS E DIREITOS CUJA EFETIVAÇÃO DECORRE DO ALCANCE DO ESTADO DE COISAS}

A necessidade de se pensar o processo em vista de uma tutela dos direitos ${ }^{68}$ exige distinguir duas espécies de direitos imbricados quando se trata de um processo estrutural. Nesse sentido e com base nos estudos de Georg H. von Wright ${ }^{69}$ acerca do termo Zweckrationalität (item 2.2 acima), uma forma de racionalidade analisa a busca de fins como um meio para fins adicionais. Após a evolução teórica já traçada é possível daí diferenciar o direito a um estado de coisas (fim) da tutela de outros direitos (fins adicionais) decorrentes do alcance daquele.

Exemplificadamente, seria distinguir: a) entre o direito à preservação da empresa do direito de crédito dos credores da recuperanda, do direito ao crédito e ao trabalho de empregados da recuperanda; b) entre o direito a um estado de coisas constitucional no sistema penitenciário nacional e o direito de determinado preso de ter respeitada sua dignidade; c) entre o direito a que $50 \%$ da população de 0 a 3 anos tenha acesso à matricula em creches e o direito a que determinada criança tenha acesso a uma vaga em creche.

O tratamento da relação entre a tutela dos direitos e processo estrutural exige referida distinção. O processo estrutural tutela de modo imediato e enquanto fim, o alcance do estado ideal de coisas, mas o faz enquanto meio, de modo extrínseco e sujeito a quebras de estabilidade (item 2.3.2) para possibilitar a tutela de outros direitos, estes não plenamente

\footnotetext{
68 MARINONI, Luiz Guilherme. Curso de Processo Civil: teoria geral do processo. $3^{\text {a }}$ ed. São Paulo: Editora Revista dos Tribunais, 2008, p. 240. MITIDIERO, Daniel. A tutela dos direitos como fim do processo civil no Estado constitucional. Revista de Processo, v. 39, n. 229, p. 51-74, mar. 2014, p. 63.

${ }^{69}$ WRIGHT, Georg Henrik von. Rationality: Means and Ends, op. cit., p. 61-62.
} 
efetiváveis antes do alcance daquele.

Em que pese tal distinção ser passível de demonstração e ser aplicável a todos os processos estruturais, tal fato assume especial importância e se torna mais evidente no que a doutrina denomina ações pseudoindividuais, às quais possuem um conteúdo coletivo, pela natureza incindível da relação jurídica substancial "de modo que a decisão deve ser do mesmo teor para todos que se encontrem na mesma situação jurídico-substancial ${ }^{70 "}$.

Novamente um exemplo pode esclarecer o que se afirma. No Estado do Ceará, nos autos da Ação Civil Pública $n^{\circ}$ 0811930-91.2016.4.05.8100, em processo que busca reestruturar a saúde pública no Estado, judicialmente, foram organizadas filas para cirurgias ortopédicas onde pacientes são chamados por ordem de indicação cirúrgica ou clara categorização de risco, tudo isso devidamente homologado ${ }^{71}$. Em tais casos, a tentativa de uma tutela imediata e simultânea do direito individual (o art. 196 da CF e art. $2^{\circ}$ da Lei n. 8.080/90), implica em dificultar ou até mesmo impedir o alcance do direito ao estado ideal de $\operatorname{coisas}^{72}$, no que fica demonstrada a distinção.

\subsection{CARACTERÍSTICAS DOS DIREITOS TUTELADOS PELO PROCESSO ESTRUTURAL}

\subsubsection{Direito que se tutela no mundo dos fatos e de modo específico}

O processo, enquanto técnica, deve possibilitar uma tutela (aqui entendida como resultado) adequada ao direito material. $\mathrm{O}$ fim do processo precisa ser identificado a partir das necessidades do direito material e do resultado que o processo deve proporcionar para atendê-las ${ }^{73}$.

\footnotetext{
${ }^{70}$ WATANABE, Kazuo. Relação entre demanda coletiva e demandas individuais. Revista de Processo. São Paulo: Revista dos Tribunais, ano 31, n. 139, p. 28-35, set. 2006.

${ }^{71}$ JFCE. Processo n ${ }^{\circ}$ 0811930-91.2016.4.05.8100. Decisão. Juíza Cintia Menezes Brunetta. 22/11/2017.

${ }^{72}$ Conforme relato da magistrada, Cíntia Menezes Brunetta, responsável pelo caso das cirurgias ortopédicas no Estado do Ceará, via de regra na atuação do judiciário nas ações de saúde "a solução encontrada pelo Poder Judiciário para esses casos acaba sendo pontual e não sustentável, gerando ainda mais conflito social e a perpetuação da instabilidade das relações dentro do sistema de saúde pública brasileiro". Prêmio Innovare. Edição XIV, 2017. Autor: Cíntia Menezes Brunetta e Mozart Ney Rolim Teixeira Henderson Categoria: Juiz. Local: Fortaleza-CE.

${ }^{73}$ MARINONI, Luiz Guilherme. Técnica processual e tutela dos direitos. $3^{\mathrm{a}}$ ed. São Paulo, Editora Revista dos Tribunais, 2010, p. 112-115.
} 
Casos há em que a tutela do direito não exige a prática de atos no mundo físico, realizando-se no plano normativo. Na clássica classificação das ações aí se enquadrariam: a) as ações meramente declaratórias, onde apenas se busca a declaração da existência, da inexistência ou do modo de ser de uma relação jurídica ${ }^{74}$ ou da autenticidade/falsidade de um documento (art. 19 do CPC) e; b) as ações constitutivas ${ }^{75}$ por meio da qual se busca a criação, modificação ou extinção de situações jurídicas ${ }^{76}$.

Por outro lado, em muitos casos, a tutela do direito exige a prática de atos no mundo físico, efetivando-se por meio da prática de atos materiais. São os direitos em que há um dever de prestação ${ }^{77}$, os quais exigem realização no mundo dos fatos. Em caso de descumprimento da prestação prevista surge para o titular (art. 189 do CC) a pretensão de exigir uma conduta (fazer, não fazer ou dar), tem-se lugar a necessidade de uma execução. Os direitos a uma prestação, são associados, na classificação trinária das ações, às ações condenatórias $^{78}$, e podem ser exemplificados por um direito de crédito, uma obrigação de construir escolas ou uma obrigação de restituir de modo específico ou pelo equivalente em dinheiro.

Dado ter por essência uma transformação no plano dos fatos (estados de coisa), os direito passíveis de tutela mediante os provimentos decorrentes de ações constitutivas e de ações meramente declaratórias não requerem, como técnica, um processo estrutural, salvo se, e na medida em que, tiverem por efeito anexo ou forem condição para, o exercício do

\footnotetext{
${ }^{74}$ Por exemplo a interpretação de uma cláusula contratual ou a inexistência de uma relação jurídica tributária.

${ }^{75}$ São ações relacionadas aos denominados direitos potestativos onde uma simples declaração, nas palavras de Pontes de Miranda, tem o condão de "influir na esfera jurídica de outrem adquirindo, modificando ou extinguindo direitos, pretensões, ações e exceções". MIRANDA, Francisco Cavalcante Pontes de. Tratado de Direito Privado. T. V. São Paulo: Editora Revista dos Tribunais. 2012, p. 297. Em tais direitos não se verifica um correspondente dever de prestar determinada conduta ação ou omissão, havendo apenas uma posição de sujeição, nesse sentido veja-se VILANOVA, Lourival. Causalidade no Direito, op. cit., p. 231.

${ }^{76}$ Por exemplo a anulação de um negócio jurídico ou investigação de paternidade.

77 Conforme anota Lourival Vilanova, se enquadram aqui os direitos subjetivos que têm por conteúdo a conduta de outrem (ação ou omissão). VILANOVA, Lourival. Causalidade no Direito, op. cit., p. 219.

${ }^{78}$ Caso se adote a classificação quinária das ações aí se incluiriam ainda as ações mandamentais e executivas. A classificação quinaria é atribuída a Pontes de Miranda para quem "A ação é classificada conforme aquilo que se espera da sentença, se a ação for julgada procedente. Se de força eficacial declarativa a sentença que se espera, declarativa chama-se a ação. Se constitutiva a eficácia da sentença que se espera, constitutiva chama-se a ação. Se condenatória, mandamental, ou executiva a sentença que se espera, condenatória, mandamental ou executiva diz-se a ação." MIRANDA, Francisco Cavalcante Pontes de. Tratado das ações. t.1. São Paulo: Editora Revista dos Tribunais, 2016, p. 135.
} 
direito a uma prestação, este sim tutelável de modo estrutural ${ }^{79}$.

Mas não basta que o direito exija ser efetivado no mundo físico, o processo estrutural é ainda uma técnica para a tutela específica do direito, uma tutela que visa proporcionar o "resultado prático atingível por meio do adimplemento, isto é, da não violação do direito ou interesse tutelado ${ }^{80 "}$ e se não de modo preciso, com a "maior coincidência possível ${ }^{81 "}$ " O processo estrutural não se presta a uma tutela pelo equivalente em dinheiro, salvo como consequência reflexa, sendo adequado, sobretudo, para os casos onde uma tutela distinta da específica implica em verdade em uma "denegação de tutela" ou um "melancólico "prêmio de consolação" "82-83.

\subsubsection{Direitos que exigem o tempo destinado ao alcance de um estado de coisas}

Há direitos que mesmo reconhecidos e já juridicamente eficazes não podem ser

\footnotetext{
${ }^{79}$ A ressalva deve ser feita e é importante. Deve ser feita porque tem se admitido na doutrina, na jurisprudência, que mesmo as ações declaratórias podem dar ensejo à execução (ZAVASCKI, Teori Albino. Sentenças declaratórias, sentenças condenatórias e eficácia executiva dos julgados. Revista de Processo. São Paulo, ano 28, n. 109, p. 45-56, jan./mar. 2003 e REsp 1114404/MG, Rel. Ministro Mauro Campbell Marques, Primeira Seção, julgado em 10/02/2010, DJe 01/03/2010). Seriam exemplos as ações declaratórias que declaram o direito a uma prestação, como ocorre na sentença que declara o direito a uma compensação tributária. Raciocínio semelhante se verifica nas ações constitutivas, dado que muitas vezes geram, como efeito anexo, o direito a uma prestação, este não aquela, exige uma alteração no plano dos fatos (DIDIER Jr., Fredie. Sentença constitutiva e execução forçada. Revista de Processo, ano 33, v. 159, p. 65-76, 2008). Seria exemplo o direito de restituição decorrente da anulação de um negócio jurídico cujas partes deverão ser restituídas até "o estado em que antes dele se achavam, e, não sendo possível restituí-las, serão indenizadas com o equivalente" (art. 182 do CC). A ressalva é importante porque em diversos processos estruturais é possível verificar a existência de uma fase procedimental que se conclui com uma declaração ou com uma constituição. Assim, por exemplo, é possível citar a teoria do estado de coisas inconstitucional em que se certifica uma inconstitucionalidade previamente ao início da execução dos atos que buscam reestruturar o estado de coisas para que este se torne constitucional. Semelhante declaração se verificou no caso Brown v. Board of Education of Topeka (Brown v. Board of Education of Topeka, 347 U.S. 483, 1954) e no caso Holt v. Server (Holt v. Sarver, 300 F. Supp. 825 - ED. Ark. 1969). O importante é separar os casos onde a declaração ou a constituição constante do provimento judicial é suficiente, por si só, para tutelar o direito, não sendo exigido nenhuma providência material, dos casos onde a declaração e a constituição constantes do provimento judicial são apenas etapas para a efetiva tutela do direito, a qual, apenas ocorrerá no plano material-fático, após técnicas processuais executivas. Estes últimos são os únicos em que se justifica analisar a necessidade ou não da tutela do direito ocorrer mediante um processo estrutural.

${ }^{80}$ MOREIRA, José Carlos Barbosa. A tutela específica do credor nas obrigações negativas. Temas de Direito Processual (Segunda Série). 2a ed. São Paulo: Saraiva, 1988, p. 31.

${ }^{81}$ MOREIRA, José Carlos Barbosa. Tendências na execução de sentenças e ordens judiciais. Temas de Direito Processual (Quarta Série). São Paulo: Saraiva, 1989, p. 215.

${ }^{82}$ MOREIRA, José Carlos Barbosa. A tutela específica do credor nas obrigações negativas, op. cit., p. 32.

${ }^{83}$ RENDLEMAN, Doug R. The Inadequate Remedy at Law Prerequisite for an Injunction. University of Florida Law Review n. 33, 1981, p. 346-358. Doug Rendleman analisa os fatores em que não é adequada uma tutela pelo equivalente em dinheiro classificando entre fatores econômicos, morais e administrativos.
} 
efetivados de modo imediato no mundo físico por questões de fato. Isso precisa ser compreendido, sob pena de serem utilizados meios que podem possuir efeito inverso ao pretendido $^{84}$.

Conforme já afirmado acima (item 2.1) acerca do caso Brown v. Board of Education of Topeka ${ }^{85-86}$, a Suprema Corte do Estados Unidos entendeu que não era possível "ainda ${ }^{87 "}$ dar efetividade ao decidido ${ }^{88}$. No exemplo, o direito certificado apresenta o tempo até o alcance do estado de coisas ideal como elemento necessário, exigindo uma alteração dos fatos para a sua efetividade. Referida consideração sobre o tempo é elemento imprescindível à configuração de um processo enquanto estrutural. Aqui "ainda" não há um direito que se possa efetivar imediatamente. Para o tratamento desses direitos, por uma alteração no plano dos fatos que permita progressivamente o alcance de sua efetivação, há o processo estrutural.

À característica de tutela específica que não pode ser efetivado de modo imediato por questões de fato acrescente-se a qualidade da questão de fato exigir um estado ideal de coisas (item 2.3.1) a ser alcançado como uma "plataforma" para tutela de direito. Exige-se uma transição entre estados de coisa $(p T q)$, uma transição $T$ de um $p$-mundo para um $q$ mundo $^{89}$.

Implica-se assim em um direito com um conteúdo complexo e mutável gradativamente, o qual carrega o contradireito do tempo necessário ao alcance do estado de coisas, sendo efetivado aquele, proporcionalmente à redução deste.

No exemplo das cirurgias ortopédicas do Estado do Ceará, tem sido buscado um

\footnotetext{
${ }^{84}$ Cite-se por exemplo a exigência de implementação de políticas públicas imediatamente impossíveis e muitas vezes buscadas "sob pena de multa". Vide a respeito crítica de Eduardo José da Fonseca Costa. In COSTA, Eduardo José da Fonseca. A "Execução Negociada" de políticas públicas em juízo. Revista de Processo. São Paulo: RT, 2012, ano 37, v. 212, p. 25-56, p. 31.

${ }^{85}$ Brown v. Board of Education of Topeka, 347 U.S. 483 (1954)

${ }^{86}$ Outro exemplo é o caso Brown v. Plata em que a Suprema Corte dos Estados Unidos determinou à Califórnia que reduzisse sua população carcerária a $137,5 \%$ da capacidade projetada. dentro de dois anos (Brown v. Plata, 563 U.S. 493, 2011).

${ }^{87}$ RENDLEMAN, Doug R. Brown II "All Deliberate Speed" at Fifty, op. cit., p. 1585-1586. O autor identifica que o tribunal não ordenou uma injunção imediata, apenas iniciou um período de transição dizendo aos juízes que mantivessem a jurisdição sobre as ações.

${ }^{88}$ Era preciso reestruturar o sistema de ensino para um regime integrado de educação e que não implicasse em maior sofrimento, era preciso alterar o estado de coisa (estado fático) existente mediante novos procedimentos para escolha de alunos e para construção de escolas, substituição dos corpos docentes, revisão do sistema de transportes com novas rotas e distâncias, modificação do currículo, etc.

${ }^{89}$ WRIGHT, Georg Henrik von. Norm and action, op. cit., p. 28.
} 
estado de coisas que permita um tempo inferior de espera para a realização das cirurgias. Atingindo diretamente a causa do estado de coisas anterior, ${ }^{90}$ se verifica, a partir do processo, a solução de entraves com a falta de material (órteses e próteses), a viabilização de convênios com mais hospitais e um gerenciamento mais apurado da fila de cirurgias, agora em lista única com inclusão de paciente apenas por meio da central de regulação do Município de Fortaleza entre outras providências. À medida que se alcança o estado de coisas que permita a realização de um maior número de cirurgias, se reduz o contradireito do tempo de alcance do estado ideal de coisas e, assim, e se efetiva gradativamente o direito à realização de cirurgias ortopédicas no Estado do Ceará. TUTELAS ESPECÍFICAS

\subsubsection{As tutelas inibitória, reintegratória (ou remoção do ilícito) e ressarcitória}

Acima (item 3.2.1) se caracterizou os direitos adequados à tutela estrutural como aqueles que se realizam no mundo dos fatos, e mais do que isso, como aqueles em que uma tutela distinta da específica implicaria em verdade em uma "denegação de tutela" ou um "melancólico "prêmio de consolação""91. Ao classificar as tutelas específicas, convém distinguir as tutelas inibitória, reintegratória (ou de remoção do ilícito) e ressarcitória específica.

Inibitória é a tutela específica que tem por fim evitar que o ilícito ocorra, ou se já ocorrido, evitar sua reiteração ou continuação ${ }^{92}$. É tutela preventiva ${ }^{93}$, voltada para o futuro. Ao se voltar contra o ilícito (ato contrário ao direito) exige a análise da probabilidade deste (ilícito) e não do dano, sua consequência meramente eventual ${ }^{94}$.

Ao não se relacionar com a tutela contra o dano não exige os elementos subjetivos do dolo ou culpa, próprios do exame necessário ao ressarcimento do dano (art. 497, par. único

\footnotetext{
90 <https://www.jfce.jus.br/todas-noticias/2414-uma-solucao-possivel-para-a-fila-das-cirurgias-ortopedicasde-alta-complexidade-no-ceara > acesso em 21.03.2019

${ }^{91}$ MOREIRA, José Carlos Barbosa. A tutela específica do credor nas obrigações negativas, op. cit., p. 32.

92 MARINONI, Luiz Guilherme. Técnica Processual e Tutela dos Direitos, op. cit., p.195.

${ }^{93}$ MOREIRA, José Carlos Barbosa. Tutela sancionatória e tutela preventiva. Temas de Direito Processual (Segunda Série). $2^{a}$ ed. São Paulo: Saraiva, 1988,p. 25.

${ }^{94}$ MARINONI, Luiz Guilherme. Técnica Processual e Tutela dos Direitos, op. cit., p.195.
} 
do CPC). São exemplos, a tutela que visa impedir a venda ou a reiteração da venda de um produto que tenha sido proibido pela legislação, ou ainda impedir o início ou a continuidade de determinada obra em local onde as normas de proteção ambiental ou de ordenação urbana não permitem construção.

A tutela reintegratória é também espécie tutela contra o ilícito, dessa vez já praticado e se voltando contra os efeitos que continuam ${ }^{95}$ após sua prática, sendo assim uma modalidade de tutela repressiva em relação ao ato contrário ao direito realizado no passado, possuindo todavia uma preventividade indireta eventual no que diz respeito a impedir a ocorrência de danos ${ }^{96} \mathrm{em}$ decorrência dos efeitos do ilícito praticado, se for o caso.

Também na tutela reintegratória não se cogita a análise de dano ou dos elementos subjetivos de dolo ou culpa (art. 497, par. único do CPC), tendo por análise unicamente os efeitos do ilícito praticado, eventualmente prevenindo danos que possam deles decorrer. Um exemplo é o caso da indústria que despeja lixo tóxico no meio ambiente. O ilícito foi o ato de despejar o lixo em local proibido, a tutela reintegratória visa remover os efeitos decorrentes deste ato, não se questionando nada acerca de eventuais danos causados. Remove-se o lixo e o que mais estiver contaminado para que sejam removidas todas as consequências do ato praticado.

Por fim, a tutela ressarcitória é a tutela contra o dano, tendo por objetivo sua reparação, é, portanto, uma tutela repressiva. Em regra, são analisados os elementos subjetivos (culpa ou dolo) para responsabilização do agente, diz em regra, por que podem ser dispensados pelo ordenamento.

A tutela ressarcitória pode ocorrer pelo equivalente em dinheiro ou na forma específica, neste caso, se busca conferir ao lesado a situação que existiria caso o dano não

\footnotetext{
${ }^{95}$ Discute-se acerca da delimitação do campo de atuação entre a tutela inibitória e da tutela reintegratória no que diz respeito aos ilícitos continuados, havendo quem entenda serem objeto de tutela inibitória, restando para a tutela reintegratória apenas a tutela contra os efeitos continuados de um ilícito exaurido. Outros, todavia, entendem tratar-se de objeto de uma tutela reintegratória tanto os ilícitos continuados quanto os efeitos continuados do ilícito exaurido. Como anota Didier Jr., Paula Sarno, Leonardo Cunha e Rafael Oliveira a discussão se resume a adoção de uma ou outra opção teórica, sendo possível registrar ao menos que a tutela inibitória se volta contra uma situação futura e a tutela reintegratória se volta contra uma situação pendente. DIDIER JR., Fredie. CUNHA, Leonardo Carneiro da. BRAGA, Paula Sarno. OLIVEIRA, Rafael Alexandria de. Curso de Direito Processual Civil: execução. $8^{\mathrm{a}}$ ed. Salvador: Ed. Jus Podivm, 2018, p. 585.

${ }^{96}$ MARINONI, Luiz Guilherme. Técnica Processual e Tutela dos Direitos, op. cit., p.206.
} 
houvesse ocorrido ${ }^{97}$. Apenas esta última é classificada como tutela específica. Como exemplos de tutela específica temos a recuperação ambiental em caso de dano ao meio ambiente, a realização de cirurgia reparatória em caso de erro em procedimento cirúrgico anterior ou o direito de resposta diante de uma publicação danosa ocorrida em um jornal.

\subsubsection{A relação entre a tutela estrutural e as tutelas específicas}

Acima se diferenciou o direito a um estado de coisas (fim) da tutela de outros direitos decorrentes (fins adicionais) do alcance daquele. Ademais se delimitou a atuação dos processos estruturais na tutela dos direitos como direito que se tutela no mundo dos fatos e de modo específico, bem como a exigência de um tempo destinado ao alcance de determinado estado de coisas. Recordadas as espécies de tutelas específicas convém esclarecer a relação que existe entre elas e o processo estrutural.

As espécies de tutela especificas (inibitória, reintegratória e ressarcitória) via de regra são prestadas por atos únicos, definidos e imediatos, como uma busca e apreensão de produtos cuja venda se quer impedir, a remoção de lixo contaminado ou a publicação de um direito de resposta no mesmo veículo em que inicialmente se veiculou informação danosa.

Ocorre que, em algumas situações, a tutela específica inibitória, reintegratória ou ressarcitória não pode realizar-se em um ato único, nem previamente definido e tão pouco imediato. Por questões de fato, uma transição entre estados de coisas é necessária para que seja possível efetivar a tutela específica necessária. Para esses casos o processo estrutural se apresenta como uma tutela meio para a tutela específica ou, em simplificação menos exata uma tutela que torna possível outra tutela. Um exemplo em cada uma das espécies de tutela específica pode auxiliar na compreensão do que se sustenta.

No caso Brown v. Board of Education of Topeka ${ }^{98}$, a Suprema Corte dos Estado Unidos conclui afirmando a existência de um ilícito: a segregação racial nas escolas públicas. A tutela deferida foi impedir que o ilícito continuasse. Mas a própria corte entendeu que não era possível o cumprimento imediato da tutela que impediria a reiteração

\footnotetext{
${ }^{97}$ MARINONI, Luiz Guilherme. Técnica Processual e Tutela dos Direitos, op. cit., p.308.

${ }^{98}$ Brown v. Board of Education of Topeka, 347 U.S. 483 (1954)
} 
do ilícito. Foi necessário um processo estrutural para viabilizar o cumprimento da tutela inibitória. Um processo que diagnosticasse as necessidades, estabelecesse os meios, o tempo e o grau para o alcance do estado de coisas ideal ${ }^{99}$, que permitiria o cumprimento da tutela inibitória e, assim, uma educação integrada nas escolas públicas.

A tutela reintegratória também pode exigir um processo estrutural. Imagine-se a concessão de uma tutela que envolvesse um acidente nuclear como o ocorrido no Brasil em 1987, em Goiânia com o Césio-137 (137Cs). Um aparelho de radioterapia abandonado foi violado e, pouco mais de 15 dias de exposição, implicou em graves consequências, gerando uma complexa e demorada remoção de efeitos do ilícito. Foi necessário identificar, monitorar e descontaminar a população envolvida ${ }^{100-101}$, bem como a remover de grandes quantidades de solo, demolir de construções ${ }^{102}$ e constante monitoração da dispersão do 137Cs com análises de solo, vegetais, animais, água e ar. A definição das ações que permitiriam os melhores resultados, a discussão das dificuldades técnicas existentes, a necessidade de monitoramento, a avaliação e a definição de novas ações, exigiriam, certamente, um processamento estrutural.

Por fim, o exemplo de tutela ressarcitória específica vem da Ação Civil Pública $n^{\circ}$ 93.8000533-4 da $1^{\text {a }}$ Vara Federal da Subseção Judiciária de Criciúma/SC - ACP do Carvão, trata-se de exemplo já clássico na doutrina brasileira de processo estrutural.

\footnotetext{
99 Pelo menos assim deveria ser. Há quem critique a decisão em referido caso pela total ausência de definições em questões importantes como parâmetros para compreender o significado de "toda velocidade deliberada" ou do que pode ser considerado um "sistema unitário" de ensino. Veja-se a respeito em RENDLEMAN, Doug R. Brown II "All Deliberate Speed" at Fifty, op. cit., p. 1.612.

100 Conforme sitio mantido pelo estado de Goiás acerca do tema foram identificados e isolados sete focos principais, onde houve a contaminação de pessoas e do ambiente e onde havia altas taxas de exposição. No total, foram monitoradas 112.800 pessoas, das quais 249 apresentaram significativa contaminação interna e/ou externa, sendo que em 120 delas a contaminação era apenas em roupas e calçados, e as mesmas foram liberadas após a descontaminação. Fonte: 〈http://www.cesio137goiania.go.gov.br/o-acidente> acesso em 24.03.2019.

${ }^{101}$ Para executar o monitoramento sobre os efeitos da exposição à radiação ionizante nas pessoas que foram vítimas deste acidente, o governo do Estado de Goiás criou, em fevereiro de 1988, a Fundação Leide das Neves Ferreira, que definiu grupos de monitoramento dos pacientes, considerando como critérios de classificação a gravidade das lesões cutâneas e a intensidade da contaminação interna e externa, e que determinou a metodologia dos protocolos de acompanhamento médico. Fonte: <http://www.cesio137goiania.go.gov.br/o-acidente> acesso em 24.03.2019.

$102 \mathrm{O}$ acidente de Goiânia gerou $3500 \mathrm{~m} 3$ de lixo radioativo, que foi acondicionado em containeres concretados. O repositório definitivo deste material localiza-se na cidade de Abadia de Goiás, a $23 \mathrm{~km}$ de Goiânia, onde a CNEN instalou o Centro Regional de Ciências Nucleares do Centro-Oeste, que executa a monitoração dos rejeitos radioativos e controle ambiental. Fonte: <http://www.cesio137goiania.go.gov.br/oacidente> acesso em 24.03.2019.
} 
Conforme anota Arenhart ${ }^{103}$, o ressarcimento específico mediante a recuperação ambiental das áreas degradadas exigiu até o momento quatro fases ${ }^{104}$, para identificação da extensão do dano, definição de estratégias para o enfrentamento do problema, apresentação e aprovação de projetos de recuperação ambiental e execução dos projetos aprovados. Tal não seria possível não fosse o seu desenvolvimento enquanto processo estrutural.

\section{CONCLUSÕES}

Há certas situações de direito material onde se apresenta necessária uma relação processual teleológica (prospectiva), que tome determinado estado fático pretendido como fim e articule meios para seu alcance. Tal relação teleológica é o que identifica o processo estrutural.

A relação teleológica dos processos estruturais, exige uma racionalidade que delibera entre meios e fins e, especialmente neste estudo, sobre os fins pretendidos como uma plataforma que possibilita o alcance de fins adicionais.

A racionalidade entre meios e fins se concretiza em uma relação entre ação e uma transição entre estados de coisa $(p T q)$, a qual é definida como expressão geral do objeto dos processos estruturais. A conclusão de referida transição possibilita a tutela de direitos.

Assim, em um processo estrutural, se distinguem duas espécies de direitos: o direito ao alcance do estado ideal de coisas e o direito que daquele depende para sua efetivação. $\mathrm{O}$ processo estrutural tutela de modo imediato, o alcance do estado ideal de coisas, mas o faz enquanto meio para possibilitar a tutela de outros direitos, estes plenamente efetiváveis antes do alcance daquele.

Os direitos tutelados pelos processos estruturais têm por características exigirem uma

\footnotetext{
${ }^{103}$ ARENHART, Sérgio Cruz. Processos Estruturais no Direito Brasileiro: Reflexões a partir do caso da ACP do Carvão, op. cit., p. 482-487.

104 A primeira fase (2000-2004), permitiu a obtenção de informações para a identificação da extensão dos danos ambientais. A segunda fase (2004-2005), implicou de estratégia para o enfrentamento do problema, mediante a exigência de uma padronização dos projetos apresentados. Na terceira fase (2006-2009), os réus obrigados a apresentar projetos segundo a padronização indicada e se criou um Grupo de Assessoramento Técnico, formado por técnicos de todas as partes e ainda externos com função de propor estratégias e técnicas para a recuperação ambiental. Na quarta fase (2009-atual), pelo cumprimento de sentença se tem efetivado o cronograma definido para recuperação ambiental com prazo de execução até 2020. Sem um processo estrutural a efetivação da tutela específica dificilmente seria obtida.
} 
realização no mundo material e voltado aos casos em que se exige uma tutela específica.

Há situações onde a tutela específica não pode realizar-se em um ato único, nem previamente definido e tão pouco de modo imediato. Por questões de fato (estado de coisas atual), a tutela específica é impossível de se efetivar imediatamente, o processo estrutural se apresenta, nestes casos, como ponte para um estado de coisas futuro onde a tutela específica se torne possível.

\section{REFERÊNCIAS}

ALEXY, Robert. Teoria da Argumentação Jurídica. $3^{\text {a }}$ ed. Rio de Janeiro: Forense, 2011 ARENHART, Sergio Cruz. Processos estruturais no direito brasileiro: reflexões a partir do caso da ACP do carvão. In: GRINOVER, Ada Pellegrini. WATANABE, Kazuo. COSTA, Susana Henriques da (Coord). O Processo Para Solução de Conflitos de Interesse Público. Salvador: Jus Podivm, 2017. p. 475-492.

. Decisões Estruturais no Direito Processual Civil Brasileiro. Revista de Processo. São Paulo: RT, 2013, ano 38, v. 225, p. 389-410.

. JOBIM, Marco Félix. (Org.). Processos Estruturais. Salvador: Juspodivm, 2017.

ÁVILA, Humberto. Teoria dos Princípios: da definição à aplicação dos princípios jurídicos. 18 . Ed. São Paulo: Malheiros, 2018.

BATISTA, Felipe Vieira. A Recuperação Judicial como Processo Coletivo. 2017. Dissertação (Mestrado em Direito) - Faculdade de Direito, Universidade Federal da Bahia, Salvador, 2017.

BERGALLO, Paola. La causa "Mendoza": una experiencia de judicialización cooperativa sobre el derecho a la salud. In: GARGARELLA, Roberto (org.). Por una justicia dialógica: el Poder Judicial como promotor de la deliberación democrática Buenos Aires: Siglo XXI Editores, 2014, e-book.

CABRAL, Antonio do Passo. Coisa julgada e preclusões dinâmicas: entre continuidade, mudança e transição de posições processuais estáveis. $3^{\text {a }}$ ed. Salvador: Jus Podivm, 2019.

CASTELO, Fernando Alcântara. Direito à Saúde e Decisões Estruturais: Por uma judicialização mais racional e eficiente. Revista de Processo. São Paulo: RT, 2017, ano 42 , v. 274 , p. $317-342$. 
CHAYES, Abram. The Role of the Judge In Public Law Litigation. Havard law review. Vol. 89, n. 7, maio de 1976. p. 1281-1316.

COSTA, Eduardo José da Fonseca. A "Execução Negociada" de políticas públicas em juízo. Revista de Processo. São Paulo: RT, 2012, ano 37, v. 212, p. 25-56.

COSTA, Susana Henriques da. Acesso à Justiça: Promessa ou Realidade? Uma análise do Litígio sobre Creche e pré-escola no Município de São Paulo. In: GRINOVER, Ada Pellegrini. WATANABE, Kazuo. COSTA, Susana Henriques da. O Processo Para Solução de Conflitos de Interesse Público. Salvador: Jus Podivm, 2017. p. 449-473.

DIDIER JR., Fredie. CUNHA, Leonardo Carneiro da. BRAGA, Paula Sarno. OLIVEIRA, Rafael Alexandria de. Curso de Direito Processual Civil: execução. $8^{\mathrm{a}}$ ed. Salvador: Ed. Jus Podivm, 2018.

Sentença constitutiva e execução forçada. Revista de Processo, ano 33, v. 159, p. 65-76, 2008.

. ZANETI JR., Hermes. OLIVEIRA, Rafael Alexandria de. Notas sobre as Decisões Estruturantes. In: JOBIM, Marco Félix. ARENHART, Sérgio Cruz (Org.). Processos Estruturais. Salvador: Jus Podivm, 2017. p. 354-368.

DWORKIN, Ronald. O Império do Direito. Tradução de Jefferson Luiz Camargo. São Paulo: Martins Fontes, 1999.

EISENBERG, Theodore. YEAZELL, Stephen C.. The Ordinary and the Extraordinary in Institutional Litigation. Havard law review. Vol. 93, n. 3, january de 1980. p. 465517.

FISS, Owen. Two models of adjudication. In: DIDIER JR. Fredie. JORDÃO, Eduardo Ferreira (coord.). Teoria do Processo: panorama doutrinário mundial. Salvador: Juspodivm, 2008. p. 761-767.

. The Supreme Court 1978 term: Foreword: the forms of justice. Havard Law Review, v. 93, n.1, 1979. p.1-58.

FULLER, Lon L. The Forms and Limits of Adjudication. Harvard Law Review, Vol. 92, No. 2, 1978, p. 353-409.

GRAVITO, César Rodrigues. El activismo dialógico y el impacto de los fallos sobre derechos sociales. In: GARGARELLA, Roberto (org.). Por una justicia dialógica: el 
Poder Judicial como promotor de la deliberación democrática Buenos Aires: Siglo

XXI Editores, 2014, e-book.

MARÇAL, Felipe Barreto. Medidas e processos estruturantes (multifocais): características e compatibilização com o ordenamento processual brasileiro. Dissertação (Mestrado em Direito) - Faculdade de Direito, Universidade do Estado do Rio de Janeiro, 2018.

MARINONI, Luiz Guilherme. Técnica processual e tutela dos direitos. $3^{\mathrm{a}}$ ed. São Paulo, Editora RT, 2010.

. Curso de Processo Civil: teoria geral do processo. $3^{\mathrm{a}}$ ed. São Paulo: Editora Revista dos Tribunais, 2008.

MELlO, Marcos Bernardes de. Teoria do Fato Jurídico: plano da eficácia: $1^{\circ}$ parte. $10^{\mathrm{a}}$ ed. São Paulo: Saraiva, 2015.

. Teoria do Fato Jurídico: plano da existência: 21ª ed. São Paulo: Saraiva, 2017.

Teoria do Fato Jurídico: plano da validade: 14ª ed. São Paulo: Saraiva, 2015.

MIRANDA, Francisco Cavalcante Pontes de. Tratado das Ações. T.1. São Paulo: Editora Revista dos Tribunais, 2016.

. Tratado de Direito Privado. São Paulo: Editora RT. 2012.

MITIDIERO, Daniel. A tutela dos direitos como fim do processo civil no Estado constitucional. Revista de Processo, v. 39, n. 229, p. 51-74, mar. 2014.

MOREIRA, José Carlos Barbosa. A tutela específica do credor nas obrigações negativas.

Temas de Direito Processual (Segunda Série). $2^{\text {a }}$ ed. São Paulo: Saraiva, 1988.

. O novo processo civil brasileiro: exposição sistemática do procedimento. $23^{\mathrm{a}} \mathrm{ed}$.

Rio de Janeiro, Forense, 2005.

- Tendências na execução de sentenças e ordens judiciais. Temas de Direito Processual (Quarta Série). São Paulo: Saraiva, 1989.

. Tutela sancionatória e tutela preventiva. Temas de Direito Processual (Segunda Série). $2^{a}$ ed. São Paulo: Saraiva, 1988.

OSNA, Gustavo. Nem “Tudo", Nem "Nada" - Decisões Estruturais e efeitos jurisdicionais complexos, In: JOBIM, Marco Félix. ARENHART, Sérgio Cruz (Org.). Processos Estruturais. Salvador: Jus Podivm, 2017. p. 177-202.

PECZENIK, Aleksander. On Law and Reason. Lexington: Springer, 2008. 
PUGA. Mariela. Litígio Estructural. Tesis Doctoral. Faculdade de Derecho de La Universidad de Buenos Aires. 2013.

RENDLEMAN, Doug R. Brown II "All Deliberate Speed" at Fifty: A Golden Anniversary or A Mid-Life Crisis for the Constitutional Injunction as a School Desegregation Remedy? San Diego Law Review. V.41, 2004, p. 1575-1616.

. The Inadequate Remedy at Law Prerequisite for an Injunction. University of Florida Law Review n. 33, 1981, p. 346-358.

Prospective Remedies in Constitutional Adjudication. West Virginia Law Review.

V. 78. N. 2, 1976, p. 155-170.

SANTOS, Helena Maria Pereira dos. VIEIRA, José Ribas. DAMASCENO, Luana Regina D’Alessandro. CHAGAS, Tayna Tavares das. Estado de Coisas Inconstitucional: Um estudo sobre os casos colombiano e brasileiro. Revista Quaestio Iuris. Vol. 08, $\mathrm{n}^{\circ}$. 04, Número Especial, Rio de Janeiro, 2015, p. 2596-2612.

TUCCI, José Rogério Cruz e. A causa de pedir no processo civil. 2. Ed. São Paulo: Editora Revista dos Tribunais, 2001.

VILANOVA, Lourival. Causalidade no Direito. $4^{\mathrm{a}}$ ed. São Paulo: Editora Revista dos Tribunais, 2000.

WATANABE, Kazuo. Relação entre demanda coletiva e demandas individuais. Revista de Processo. São Paulo: Revista dos Tribunais, ano 31, n. 139, p. 28-35, set. 2006.

WEBER, Max. Economia e Sociedade: fundamentos da sociologia compreensiva. V. 1. $3^{\mathrm{a}}$

Ed. Tradução de Regis Barbosa e Karen Elsabe Barbosa. Brasília, Editora Universidade de Brasília, 2000.

WRIGHT, Georg Henrik von. Explanation and Understanding. Cornell University Press. Ithaca, New York, 1971. . Norm and action: a logical enquiry. Londres, Routledge \& Kegan Paul, 1963. Rationality: Means and Ends. Rivista/Journal Epistemologia IX, Genova, Casa Editrice Tilgher-Genova sas, 1986.p. 57-72.

ZAVASCKI, Teori Albino. Sentenças declaratórias, sentenças condenatórias e eficácia executiva dos julgados. Revista de Processo. São Paulo, ano 28, n. 109, p. 45-56, 2003. 